\title{
Eradication Failure of Helicobacter Pylori Among Children's Population
}

\author{
Poul Minochkine ${ }^{1 *}$ and Kirill Telitsyn ${ }^{2}$ \\ ${ }^{1}$ Associate professor of Department of Children's Diseases, Russia \\ ${ }^{2}$ Assistant professor, Russia
}

Received: 畊 November 20, 2018; Published: 盋 November 26, 2018

*Corresponding author: Poul Minochkine, PhD, Associate Professor of Department of Children's Diseases, Russia

\section{Short Communication}

Helicobacter pylori (H. pylori) is a Gram-negative bacterium responsible for the development of gastritis that may further progress to more severe conditions, peptic ulcer disease and gastric cancer [1,2]. H. pylori have infected from $80 \%$ to $90 \%$ of the population in Russia [3]. Despite the ongoing discussion on which H. pylori infected patients should be treated up till full eradication of the infection, eradication depending on the prevalence of strains resistant to antibacterial preparations using for treatment [4]. Currently, the eradication of $\mathrm{H}$. pylori is managed by the use of a triple therapy, involving the co-administration of two antibiotics and a proton pump inhibitor or bismuth during ten or fourteen days $[4,5]$. The resistance of $\mathrm{H}$. pylori to antibiotic is a key problem to all bacteria, gaining importance if leads to treatment failure [6]. Even with the current most effective treatment regimens, about $10 \%$ to $20 \%$ of patients will fail to eradicate Helicobacter pylori infection [7]. The study of eradication failure in Russian Federation was not found, more over in the Khanty-Mansiysk Autonomous Okrug Ugra was not found as well. The most prescribed preparations are the Macrolides, Fluoroquinolones, Amoxicillin, Nitroimidazoles, Tetracycline among others. At the same time among the antibiotics applied in schemes of eradication $\mathrm{H}$. pylori of the first line, most the problem of resistance is particularly actually to a Clarithromycin [8]. According to work of De Francesco and others in the world population the following indicators of resistance of $\mathrm{H}$. pylori to antibiotics in schemes of eradication therapy Table 1 are noted [9].

The purpose of our investigation was study of the eradication failure among children population in the Khanty-Mansiysk Autonomous Okrug - Ugra of Russian Federation. We used data acquisition about the most often administrated schemes of eradication therapy in practice of children's gastroenterology department. The study population included retrospective data from 50 patients from 6 to 17 years old who had received eradication therapy from May 2018 to October 2018 in the Khanty-Mansiysk Autonomous Okrug - Ugra, Nizhnevartovsk District Children's Hospital. Including criteria was functional dyspepsia and gastritis, also stomach ulcer duodenit. Contamination of Helicobacter pylori was confirmed by performance of non-invasive urea respiratory test and rapid urea test $[10,11]$. Key indicators of patients are presented in the Table 2. Dosages of the medicines used in therapy are shown as well in the Table 2.

Table 1: Percentage of resistance to drugs for eradication of $\mathrm{H}$ pylori.

\begin{tabular}{|c|c|}
\hline Drug & Percentage of resistance \\
\hline Metronidazole & $26,7 \%$ \\
\hline Clarithromycin & $17,2 \%$ \\
\hline Levofloxacin & $16,2 \%$ \\
\hline Amoxicillin & $11,2 \%$ \\
\hline Tetracyclin & $5,9 \%$ \\
\hline Rifabutin & $1,4 \%$ \\
\hline Polyresistance & $9,6 \%$ \\
\hline
\end{tabular}

Table 2: The main indicators of patients included in the research.

\begin{tabular}{|c|c|}
\hline Patient characteristic & Patients (n=50) \\
\hline Male & $36(72 \%)$ \\
\hline Female & $14(28 \%)$ \\
\hline Median of age (LQ-UQ) (years) & $12.6(6-17)$ \\
\hline \multicolumn{2}{|c|}{ Diagnosis } \\
\hline Functional dyspepsia & $8(16 \%)$ \\
\hline Gastritis and duodenitis & $29(58 \%)$ \\
\hline Stomach ulcer & $2(4 \%)$ \\
\hline Duodenal ulcer & $11(22 \%)$ \\
\hline
\end{tabular}

The choice of eradication therapy depended on a set of factors, such as primacy of contamination, clinical, laboratory and endoscopic characteristic of the disease, existence of associated diseases and complications, the Table 3. Duration of therapy was 10 days. Control of efficiency was carried out in two months after 
therapy. Patients were recommended to pass the urea respiratory test or Helicobacter pylori stool antigen tests [12]. Various diseases associated with H. pylori have been diagnosed for the studied patients. The most frequent pathologies gastritis and duodenitis-29 (58\%). Duodenal ulcer was at $11(22 \%)$ and Stomach ulcer was at 2 (4\%). In all children, H. pylori infection was confirmed, and the therapy presented in the Table 4. Unfortunately, many children showed H. pylori resistance to the first eradication therapy. This category of patients went to the clinic for the second time, and $\mathrm{H}$. pylori was also detected during repeated control testing. The data of patients with primary and secondary therapies are given in Table 5.

Table 4: Helicobacter pylori eradication protocols.

\begin{tabular}{|c|c|c|c|c|c|c|}
\hline Protocol & $\begin{array}{c}\text { proton pump } \\
\text { inhibitor }+ \\
\text { amoxicillin }+ \\
\text { metronidazole }\end{array}$ & $\begin{array}{c}\text { proton pump } \\
\text { inhibitor }+ \\
\text { amoxicillin }+ \\
\text { clarithromycin }\end{array}$ & $\begin{array}{c}\text { proton pump inhibitor }+ \\
\text { amoxicill+nitroimidazole } \\
\text { inhibitor }+\end{array}$ & $\begin{array}{c}\text { proton pump } \\
\text { nitroimidazole } \\
\text { inhibitor }+ \\
\text { amoxicillin }+ \\
\text { clarithromycin }\end{array}$ & $\begin{array}{c}\text { proton pump } \\
\text { inhibitor }+ \\
\text { amomicillin }+ \\
\text { clarithromycin } \\
+ \text { bismuth } \\
\text { metronidazole } \\
+ \text { bismuth }\end{array}$ & $\begin{array}{c}\text { proton pump } \\
\text { inhibitor }+ \\
\text { amoxicillin }+ \\
\text { nitroimidazole } \\
+ \text { bismuth }\end{array}$ \\
\hline Quantity & $12(24 \%)$ & $7(14 \%)$ & $1(2 \%)$ & $1(2 \%)$ & $22(44 \%)$ & $6(12 \%)$ \\
\hline
\end{tabular}

Table 5: Regimens for Helicobacter pylori therapy.

\begin{tabular}{|c|c|c|c|c|c|c|c|c|c|}
\hline \multicolumn{10}{|c|}{ Total HP eradication } \\
\hline \multicolumn{4}{|c|}{ Line of the therapy } & \multicolumn{6}{|c|}{ Quantity } \\
\hline \multicolumn{4}{|c|}{ Firstone therapy } & \multicolumn{6}{|c|}{$34(68 \%)$} \\
\hline \multicolumn{4}{|c|}{ Second therapy } & \multicolumn{6}{|c|}{$14(32 \%)$} \\
\hline \multicolumn{10}{|c|}{ Regimens for Helicobacter pylori therapy in different children's age groups } \\
\hline Years old of children & 6 & 9 & 11 & 12 & 13 & 14 & 15 & 16 & 17 \\
\hline Firstone therapy & $2(100 \%)$ & $3(100 \%)$ & $3(100 \%)$ & $4(100 \%)$ & $4(80 \%)$ & $5(84 \%)$ & $3(50 \%)$ & $5(84 \%)$ & $5(36 \%)$ \\
\hline Second therapy & & & & & $1(20 \%)$ & $1(16 \%)$ & $3(50 \%)$ & $1(16 \%)$ & $9(64 \%)$ \\
\hline
\end{tabular}

Table 6: Inefficient protocols.

\begin{tabular}{|c|c|c|c|c|c|c|}
\hline Protocol & $\begin{array}{l}\text { proton pump } \\
\text { inhibitor + } \\
\text { amoxicillin + } \\
\text { metronidazole }\end{array}$ & $\begin{array}{l}\text { proton pump } \\
\text { inhibitor + } \\
\text { amoxicillin + } \\
\text { clarithromycin }\end{array}$ & $\begin{array}{l}\text { proton pump } \\
\text { inhibitor + } \\
\text { amoxicillin + } \\
\text { nitroimidazole }\end{array}$ & $\begin{array}{c}\text { proton pump inhibitor } \\
+ \text { amoxicillin }+ \\
\text { clarithromycin }+ \\
\text { bismuth }\end{array}$ & $\begin{array}{c}\text { Proton pump } \\
\text { inhibitor }+ \\
\text { amoxicillin }+ \\
\text { metronidazole }+ \\
\text { bismuth }\end{array}$ & $\begin{array}{c}\text { proton pump } \\
\text { inhibitor }+ \\
\text { amoxicillin }+ \\
\text { nitroimidazole }+ \\
\text { bismuth }\end{array}$ \\
\hline Quantity & $2(14 \%)$ & $5(36 \%)$ & $2(14 \%)$ & $1(7 \%)$ & $1(7 \%)$ & $3(21 \%)$ \\
\hline
\end{tabular}

Table 7: Unwanted effect of HP Eradication Protocol.

\begin{tabular}{|c|c|c|}
\hline Unwanted effect & HP Eradication Protocol & Frequency \\
\hline \multirow[t]{2}{*}{ Nausea } & proton pump inhibitor + amoxicillin + clarithromycin + bismuth & 7 \\
\hline & proton pump inhibitor + amoxicillin + clarithromycin & 3 \\
\hline \multirow[t]{2}{*}{ Change in taste } & proton pump inhibitor + amoxicillin + clarithromycin + bismuth & 2 \\
\hline & proton pump inhibitor + amoxicillin + metronidazole + bismuth & 1 \\
\hline Allergic rash & proton pump inhibitor + amoxicillin + metronidazole & 1 \\
\hline Constipation & proton pump inhibitor + amoxicillin + clarithromycin + bismuth & 1 \\
\hline Diarrhea & proton pump inhibitor + amoxicillin + metronidazole & 1 \\
\hline \multicolumn{3}{|c|}{ Quantity of unwanted effects } \\
\hline Triple therapy & 11 & \\
\hline Quadruple therapy & 5 & \\
\hline Total & 16 & \\
\hline
\end{tabular}


The data of 14 therapies, conducted earlier and proved to be ineffective, are shown in Table 6 . In addition to the resistance of H. pylori to antibiotic therapy, we faced with undesirable effects from eradication therapy. Adverse effects which were mild and did not require the cessation of therapy, are reflected in Table 7. From the conducted study, it is noted that four-component eradication therapy with clarithromycin and bismuth showed the largest number of undesirable effects - 10 , which corresponds to $45 \%$ of all prescriptions of this protocol. However, it is worth noting that the undesirable effects were mild and did not require the cessation of therapy. Considering that only 1 case of ineffectiveness of this quadrotherapy has been registered, we believe that the continuation of its prescription is reasonable in our locality but requires further observation. There is alarming evidence that, in almost $32 \%$ of the cases, H. pylori is resistant to eradication therapy, which has resulted in repeated hospitalization and the prescription of a second eradication course. The first line protocol: proton pump inhibitor + amoxicillin + clarithromycin - 36\% of the failures in H. pylori eradication. Referring to the data of Maastricht $\mathrm{V}$, it is possible to make an assumption about the ineffectiveness of 10-day protocols in our region and the need for 14 days of the therapy [4]. However, given the high prevalence of $\mathrm{H}$. pylori in Russia, repeated reinfection with a pathogen is quite probable, especially among children's groups. This study is a new step for us in order to increase the effectiveness of treatment of children in our clinic, and it will be further continued.

\section{References}

1. Mc Coll KE (2010) Helicobacter pylori infection. N Engl J Med 362 (17): $1597-1604$.

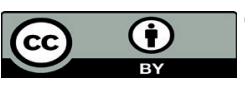

This work is licensed under Creative Commons Attribution 4.0 License

To Submit Your Article Click Here: Submit Article

DOI: $10.32474 / \mathrm{CTGH} .2018 .01 .000121$
2. Hunt RH (2006) Risks of untreated H pylori infection AGA Institute Postgraduate Course pp. 333-348.

3. Abdulhakov RA (2002) Prevalence of Helicobacter pylori Kazan Medical Journal. pp. 365-367.

4. Malfertheiner P, Megraud F, O Morain C (2017) Management of Helicobacter pylori infection-the Maastricht $\mathrm{V}$ Florence Consensus Report. Gut 66(1): 6-30.

5. Fallone CA, Chiba N, van Zanten SV (2016) The Toronto consensus for the treatment of Helicobacter pylori infection in adults. Gastroenterology 151(1): 51-69.

6. Graham DY, Lee YC, Wu MS (2014) Rational Helicobacter pylori therapy: evidence-based medicine rather than medicine-based evidence. Clin Gastroenterol Hepatol 12: 177-186.

7. Javier P GisbertJosé, María Pajares (2003) Treatment of helicobacter pylori eradication failure.Current Treatment Options in Gastroenterology 6(2): 147-156.

8. Megraud FH (2004) pylori antibiotic resistance: prevalence, impotance and advances in testing. Gut 53(9): 1374-1384.

9. Vincenzo De Francesco (2010) Floriana Giorgio Worldwide H. pylori antibiotic resistance: a systematic review. JGLD 19(4): 409-414.

10. Parente F, Bianchi Porro G (2001) The (13)C-urea breath test for noninvasive diagnosis of Helicobacter pylori infection:which procedure and which measuring equipment? Eur J Gastroenterol Hepatol 13: 803-806.

11. Goh KL, Parasakthi N, Peh SC, Puthucheary SD, Wong NW (1994) The rapid urease test in the diagnosis of Helicobacter pylori infection. Singap Med J 35: 161-162.

12. Malfertheiner P, Megraud F, O Morain CA, Atherton J, Axon AT, et al. (2012) Management of Helicobacter pylori infection the Maastricht IV/ Florence Consensus Report. Gut 61: 646-664.

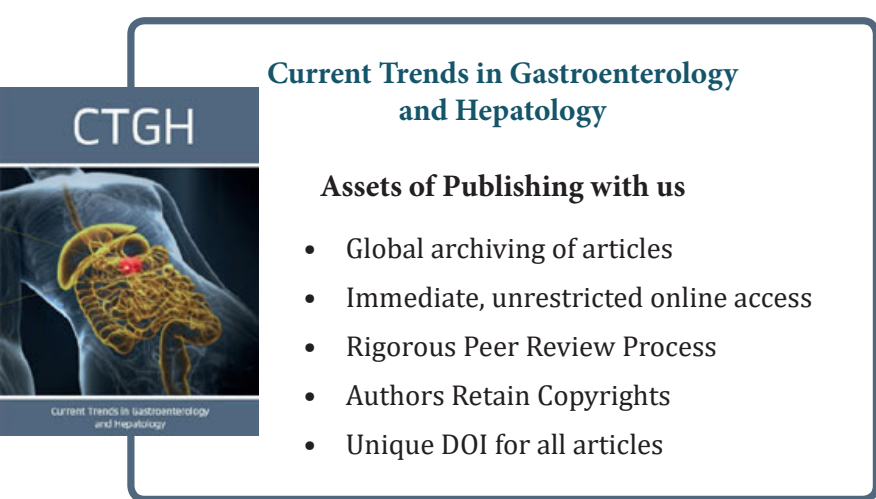

